\title{
Correlation of Pleistocene sediments from boreholes in the Ludwigshafen area, western Heidelberg Basin
}

\author{
Michael Weidenfeller \& Maria Knipping *)
}

\begin{abstract}
Cores from several boreholes in the Ludwigshafen area were analysed to investigate their sedimentology, palynology, palaeomagnetics, rock magnetics and heavy mineral composition. The preliminary results are presented from the new Ludwigshafen-Parkinsel borehole P35, which was drilled $500 \mathrm{~m}$ WSW of borehole P34, to a total depth of $300 \mathrm{~m}$. Correlation between the two boreholes reveals similarities and dissimilarities in stratigraphy, structure and the thickness of the sediments. As a result of core documentation and the preliminary evaluation of the investigation results, a good correlation is established between the coarse and fine-grained sequences in both boreholes down to a depth of $122 \mathrm{~m}$. However, the Plio-Pleistocene boundary in borehole P35 is much deeper than in P34. A fault throw of $42 \mathrm{~m}$ is assumed, attributable to young tectonics. The poor correlation between the thicknesses of the sediments in the lower sections of the two boreholes suggests that tectonism was particularly active in the Pliocene and Lower Pleistocene. The different occurrence of interglacial sequences in the two Ludwigshafen boreholes can be attributed to fluvial dynamics and neotectonic events. Further palynological analysis is required to determine whether the alternation of at least five interglacial periods determined in the Ludwigshafen-Parkinsel P34 borehole, can also be confirmed in the P35 borehole. The information gained so far from the correlation of the already analysed Middle Pleistocene interglacials in the Ludwigshafen/Mannheim area, as well as the links with the primarily Lower Pleistocene sections in Schifferstadt, already suggest that this would allow a much better understanding of the changes in vegetation and climate during the Pleistocene.
\end{abstract}

\section{[Korrelation pleistozäner Sedimente aus Bohrungen im Raum Ludwigshafen, westliches Heidelberger Becken]}

Kurzfassung: Im Raum Ludwigshafen wurden mehrere Kernbohrungen sedimentologisch, palynologisch, paläomagnetisch, gesteinsmagnetisch und schwermineralogisch untersucht. Erste Ergebnisse der neuen Bohrung Ludwigshafen-Parkinsel P35 werden vorgestellt, die $500 \mathrm{~m}$ WSW der Bohrung P34 bis $300 \mathrm{~m}$ abgeteuft wurde. Die Gegenüberstellung beider Bohrungen zeigt Übereinstimmungen, aber auch Unterschiede im Aufbau, Struktur und Mächtigkeit der Sedimente. Nach der Bohrkerndokumentation und ersten Auswertungen von Untersuchungsergebnissen lassen sich die grob- und feinkörnigen Sequenzen aus beiden Bohrungen bis in eine Teufe von $122 \mathrm{~m}$ gut miteinander korrelieren. Allerdings liegt die Plio-/Pleistozängrenze in der Bohrung P35 deutlich tiefer. Wahrscheinlich ist ein Versatzbetrag von $42 \mathrm{~m}$ anzunehmen, der auf junge Tektonik zurückzuführen ist. Die geringe Übereinstimmung der Mächtigkeiten in den tieferen Abschnitten der Bohrungen lässt vermuten, dass die Tektonik besonders im Pliozän und Unterpleistozän aktiv war. Die unterschiedliche Präsenz von warmzeitlichen Sequenzen in den beiden Ludwigshafener Bohrungen kann auf fluviale Dynamik und neotektonische Ereignisse zurückgeführt werden. Ob die in der Bohrung Ludwigshafen Parkinsel P34 erfassten Wechsel von mindestens 5 Warmzeiten auch in der Bohrung P35 bestätigt werden können, bleibt weiteren palynologischen Untersuchungen vorbehalten. Schon jetzt lässt die Korrelation zwischen den bereits bearbeiteten mittelpleistozänen Warmzeiten im Raum Ludwigshafen/Mannheim sowie die Verknüpfung mit den überwiegend altpleistozänen Abschnitten von Schifferstadt eine deutliche Kenntniserweiterung der pleistozänen Vegetations- und Klimaentwicklung erwarten.

Keywords: Upper Rhine Graben, Heidelberg Basin, Pleistocene, fluvial sediments, pollen analysis, neotectonics

\footnotetext{
*Adresses of authors: M. Weidenfeller, Landesamt für Geologie und Bergbau Rheinland-Pfalz, Emy-Roeder-Straße 5, 55129 Mainz. E-Mail: michael.weidenfeller@lgb-rlp.de; M. Knipping, Universität Hohenheim, Institut für Botanik, Garbenstraße 30, 70593 Stuttgart. E-Mail: knipping@uni-hohenheim.de
} 


\section{Introduction}

To investigate hydrogeological aspects, numerous boreholes were cored in the Ludwigshafen/ Mannheim area in recent years. These cores were analysed using a wide range of methods (Fig. 1, Table 1). The results of the Ludwigshafen-Parkinsel P34 borehole in particular - which was drilled to a TD (total depth) of $300 \mathrm{~m}$ in 2002 with $95 \%$ core recovery - provided a great deal of new information on the history of the river Rhine and the changes in vegetation and climate in the northern Upper Rhine Graben during the Pleistocene (WeidenfEller \& KÄrCher 2008).
Of particular value were the palynological analyses (KNIPPING 2008), heavy mineral analyses (Hagedorn \& Boenigk 2008) and the palaeomagnetic and rock-magnetic analyses (RoLF et al. 2008). This made it possible for the first time to reliably detect the Plio-Pleistocene boundary in the northern Upper Rhine Graben in a core, confirmed by various independent methods. Another core of $300 \mathrm{~m}$ (P35) was drilled approximately $500 \mathrm{~m}$ WSW from borehole P34 in 2006. P35 was analysed using a very similar range of methods. The results are presented in this paper, including a preliminary correlation between the two boreholes.

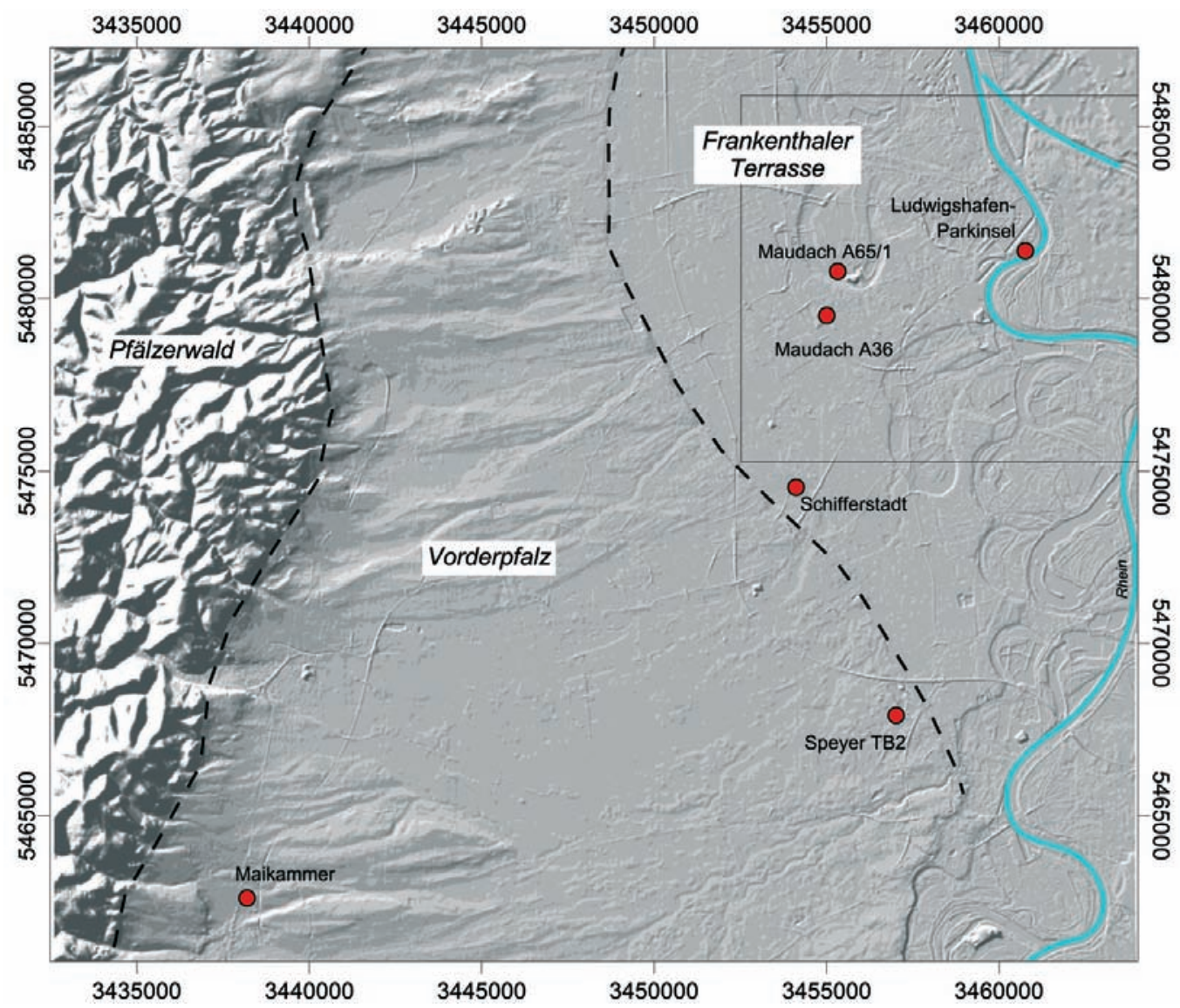

Fig. 1: Position of the investigated boreholes in the Vorderpfalz, on the Frankenthal Terrace and in the Ludwigshafen area.

Abb. 1: Lage untersuchter Bohrungen in der Vorderpfalz, auf der Frankenthaler Terrasse und im Raum Ludwigshafen. 
The results of the P34 and P35 cores are the key for the interpretation of the unconsolidated sedimentary sequences in the Ludwigshafen/ Mannheim area. The sequences in both cores are characterised by alternating coarse-grained and fine-grained horizons. They are stratigraphically subdivided using a hydrogeological terminology (BARTZ 1959, 1974, KÄRCHER 1987 ) into aquifers (Oberes Kieslager "OKL" (Upper Gravels), Mittlere sandig-kiesige Folge (Middle Sandy-Gravely Series), Untere sandigsiltige Folge (Lower Sandy-Silty Series)) and Zwischenhorizonte (intermediate horizons)
(Oberer Zwischenhorizont "OZH" (Upper Intermediate Horizon), Unterer Zwischenhorizont "UZH" (Lower Intermediate Horizon)). Reddish-brown sandy sediments were encountered in some sections and interpreted on the basis of heavy mineralogical analysis as fans deriving from the Pfälzerwald (HAGEDORN 2004, Hagedorn \& Boenigk 2008).

Whereas the stratigraphic position of the Lower Pleistocene sediments is uncertain, the upper gravels ("OKL") are conventionally attributed to a Weichselian age and referred to in the terminology of terrace division as a Lower

Table 1: Investigations of cores from boreholes Ludwigshafen-Parkinsel P34, P35 and Ludwigshafen-Maudach A36, TK 256516 Mannheim-Südwest

Tab. 1 : Untersuchungen an Kernen der Bohrungen Ludwigshafen-Parkinsel P34, P35 und LudwigshafenMaudach A36, TK 256516 Mannheim-Südwest

\begin{tabular}{|c|c|c|c|}
\hline & Lu-Parkinsel P34 & Lu-Parkinsel P35 & Lu-Maudach A36 \\
\hline Coordinate (R-Wert) & 3460666 & 3460230 & 3454850 \\
\hline Coordinate (H-Wert) & 5481069 & 5480990 & 5479490 \\
\hline Depth & $300 \mathrm{~m}$ & $300 \mathrm{~m}$ & $50.6 \mathrm{~m}$ \\
\hline Surface & $92 \mathrm{~m} \mathrm{NN}$ & $92 \mathrm{~m} \mathrm{NN}$ & $97 \mathrm{~m} \mathrm{NN}$ \\
\hline $\begin{array}{l}\text { Description of the borehole } \\
\text { sections }\end{array}$ & $\begin{array}{l}\text { WEIDENFELLER } \\
\text { (unpublished) }\end{array}$ & $\begin{array}{l}\text { WEIDENFELLER } \\
\text { (unpublished) }\end{array}$ & $\begin{array}{l}\text { WEIDENFELLER } \\
\text { (unpublished) }\end{array}$ \\
\hline Lithofacies & $\begin{array}{l}\text { HAGEDORN (2004), } \\
\text { WEIDENFELLER \& } \\
\text { KÄRCHER (2008) }\end{array}$ & this volume & - \\
\hline Sedimentology & $\begin{array}{l}\text { Kontny \& Schulte } \\
\quad \text { (unpublished) }\end{array}$ & $\begin{array}{l}\text { SiRocco \& SCHABER } \\
\quad \text { (unpublished) }\end{array}$ & - \\
\hline Gamma Log & $\begin{array}{l}\text { BLM, München } \\
\text { (unpublished) }\end{array}$ & $\begin{array}{l}\text { BLM, München } \\
\text { (unpublished) }\end{array}$ & - \\
\hline Thermal conductivity & - & WERNER (2006) & - \\
\hline Thin-section investigations & Menzies (2006) & - & - \\
\hline Pollen analysis & $\begin{array}{l}\text { KNIPPING }(2008 \text {, in } \\
\text { progress })\end{array}$ & KNIPPING (in progress) & $\begin{array}{l}\text { KNIPPING (in } \\
\text { progress) }\end{array}$ \\
\hline Heavy minerals & $\begin{array}{c}\text { Hagedorn (2004), } \\
\text { Hagedorn \& BoENIGK } \\
(2008)\end{array}$ & $\begin{array}{l}\text { HoSELMANN (in } \\
\text { progress) }\end{array}$ & - \\
\hline $\begin{array}{l}\text { Palaeomagnetic investigations/ } \\
\text { Susceptibility/ rock magnetic } \\
\text { investigations }\end{array}$ & Rolf et al. (2008) & $\begin{array}{c}\text { RoLF \& HAMBACH (in } \\
\text { progress) }\end{array}$ & - \\
\hline Clay mineralogy & - & $\begin{array}{l}\text { ELSASS et al. (in } \\
\text { progress) }\end{array}$ & - \\
\hline Molluscs & WEDEL (2008) & WEDEL (2008) & WEDEL (2008) \\
\hline
\end{tabular}


terrace (KÄRCHER 1987). Accordingly, the interpretation of the upper aquitard (Oberer Zwischenhorizont "OZH") as an Eemian formation seems doubtful, which is confirmed by the research of ENGESSER \& MüNZING (1991), RÄHLE (2005) and Wedel (2008). Pollen analytical research by KNIPPING (2004, 2008) in the Mannheim area and on drillings at Schifferstadt (Fig. 1) and P34 indicates a Middle Pleistocene age (most probably Cromerian) for the OZH. Such positioning is further supported by palaeomagnetism measurements (RoLF et al. 2008), that indicate first reversal magnetism (780 ka, MatuyamaBrunhes boundary) to be positioned below the upper aquitard. The base of the Quaternary (Gauss-Matuyama boundary) at $177 \mathrm{~m}$ below surface in P34 is clearly deeper situated than in Schifferstadt and Speyer TB2 (Fig.1). This prompted HAGEDORN (2004) to assume that the northeastern part of the central Graben block is being downthrown by active tectonism.

The rock magnetic investigations (RoLF et al. 2008) together with results of heavy mineral analyses (HAGEDORN \& BoENIGK 2008) show a clearly structured sediment profile in P34. It was possible to identify the change from mainly locally controlled sedimentation of the graben margins to a more distinct alpine controlled sedimentation at a depth of $177 \mathrm{~m}$ (G/M-boundary) by magnetic data. Based on lithostratigraphic correlation with other sedimentary records from the URG and also based on palynological evidence, this event happened at the end of Late Pliocene during a time of normal polarity of the Earth's magnetic field (Gauss Chron?). The well-documented characteristic change in magneto-mineralogy from goethite to greigite almost at the same stratigraphic level, was interpreted solely as a climatic signal (RoLF et al. 2008) which can be correlated with the global climate change at $\sim 2.5 \mathrm{Ma}$ that is well documented in deepsea sediments (SHACKLEton et al. 1984), loess deposits (HeLler \& LiU 1982) and fluvio-lacustrine sediments (HAN et al. 1997).

The heavy mineral spectrum in the Pliocene sediments confirms that the only erosional ma- terial entering the Upper Rhine Graben came from the graben margins. Whether or not it is possible to subdivide the Pliocene sequences further depends on the results of additional investigations. In the uppermost Pliocene, the connection of the Palaeo-Rhine to the Alpine drainage system changed the heavy mineral spectrum of the Rhine sediments and led to a dominance of Alpine minerals (HAGEDORN \& Boenigk 2008). The boreholes drilled in the Ludwigshafen area revealed changes in the position of the river bed. Whilst the Rhine deposited sediments on the western margin of the northern graben during the Pliocene and at the beginning of the Quaternary, the river bed moved to further east during the subsequent period because the western margin is primarily dominated by sediments deriving from the Pfälzerwald. The situation further to the east is different because the sediments are dominated here by the Alpine heavy mineral spectrum. Because of the rapid subsidence of the eastern margin of the graben (Heidelberg Basin) it is conceivable that the bed of the river Rhine was located in this area of tectonic subsidence (ELLWANGER et al. 2005). Renewed sedimentation by the Rhine in the western part of the northern Upper Rhine Graben did not start again before the deposition of the Upper Gravels during the Weichsellian glaciations, as seen on the Frankenthal Terrace (WEIDENFELLER \& KÄRCHER 2008).

\section{Results}

The Upper Gravels (OKL) consist of arenaceous medium gravel to coarse gravel of up to $20 \mathrm{~m}$ in both cores. The OKL can be divided into two sections in both boreholes. The upper section consists of coarse gravel, extends in each case to a depth of $13 \mathrm{~m}$, and is characterised by fining upwards from $10 \mathrm{~m}$ to $1 \mathrm{~m}$ depth. This is underlain by interbedded coarse sands and fine to medium gravels down to a depth of $19.5 \mathrm{~m}$. A coarse-grained facies is only present in the Upper Gravels. The underlying sediments are distinctly finer grained (sandygravelly in the middle aquifer, and sandy-silty 

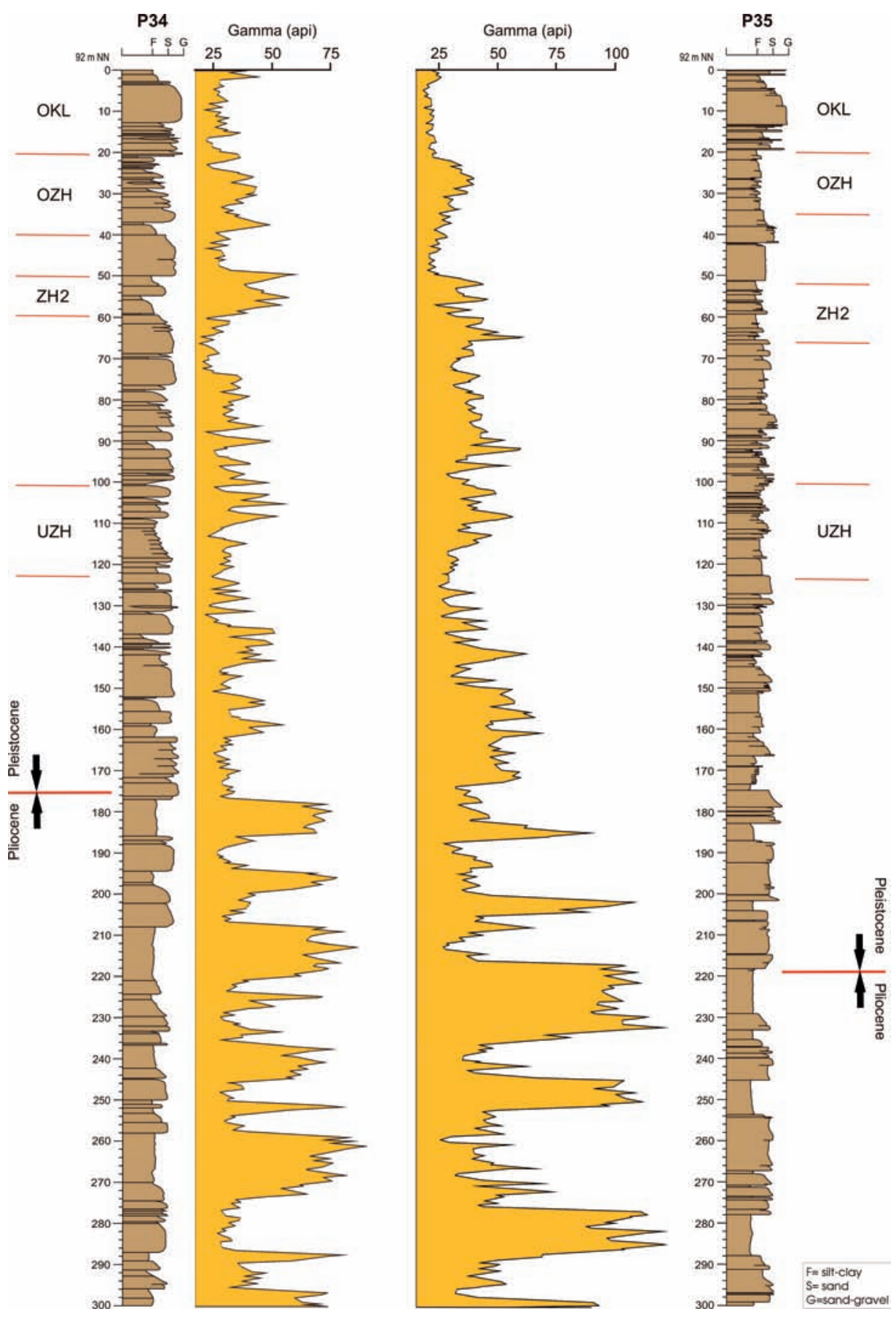

Fig. 2: Correlation of the lithofacies sections and Gamma Ray logs in the Ludwigshafen P34 and P35 boreholes.

Abb. 2: Gegenüberstellung der Lithofaziesprofile und Gamma-Logs der Bohrungen Ludwigshafen P34 und P35. 
in the lower aquifer). The OKL is underlain by the Upper Intermediate Horizon $(\mathrm{OZH})$ which is widely distributed in the northern Upper Rhine Graben, in the same way as the OKL. The OZH is located in borehole P34 between $21 \mathrm{~m}$ to $40 \mathrm{~m}$, and in borehole P35 between $19.5 \mathrm{~m}$ to approximately $34 \mathrm{~m}$ depth (Fig. 2). The interbeds of the aquitard are clayey-silty and frequently contain organic intercalations of peat or turfy moulder.

The OZH in both boreholes is underlain to a depth of $101 \mathrm{~m}$ by a medium to coarse sandy sequence containing only subordinate and thin horizons of fine gravel. A silty-sandy intermediate horizon with interbedded organic horizons (ZH2) occurs in borehole P34 between 50 $\mathrm{m}$ and $60 \mathrm{~m}$ depth, and between $51 \mathrm{~m}$ and 66 $\mathrm{m}$ depth in borehole P35. This is followed by a medium to coarse sandy section which reaches a depth of approximately $87 \mathrm{~m}$ in both boreholes, underlain in P34 by fine-grained sediments with organic horizons down to a depth of about $92 \mathrm{~m}$; and down to a depth of $98 \mathrm{~m}$ in P35. A distinct intermediate horizon, termed the Unterer Zwischenhorizont (Lower Intermediate Horizon) (UZH), occurs at a depth of 101 $\mathrm{m}$ to $122 \mathrm{~m}$ in both boreholes, and also contains several organic horizons. The sequence below $122 \mathrm{~m}$ is dominated by interbedded fine to medium-grained sand with intercalations of clayey-silty horizons. Borehole P35 has slightly thicker fine-grained sections between $151 \mathrm{~m}$ to $163 \mathrm{~m}, 167 \mathrm{~m}$ to $175 \mathrm{~m}, 183 \mathrm{~m}$ to $187 \mathrm{~m}$ and from $201,5 \mathrm{~m}$ to $204 \mathrm{~m}$. According to the current status of the analysis, the finegrained sections between $122 \mathrm{~m}$ to $183 \mathrm{~m}$ in borehole P35, are much thinner or completely absent in borehole P34. Coarser horizons with fine to medium gravel first occur between 162 $\mathrm{m}$ to $167 \mathrm{~m}$ in P34 and between $175 \mathrm{~m}$ to 183 $\mathrm{m}$ in P35.

There is a good correlation between the sediments in both boreholes from $0 \mathrm{~m}$ to $122 \mathrm{~m}$ depth - as also highlighted by a comparison of the Gamma Ray logs run in both boreholes (Fig. 2). This changes between $122 \mathrm{~m}$ to 183 $\mathrm{m}$ where the boreholes have different lithofacies profiles and Gamma Ray logs. The distinct change of the facies at $177 \mathrm{~m}$ depth in borehole P34, which is also interpreted as the Plio-Pleistocene boundary (KNIPPING 2008, RolF et al. 2008), does not occur in borehole P35 until a depth of $183 \mathrm{~m}$. The more than $10 \mathrm{~m}$-thick finegrained sequence lying beneath the Plio-Pleistocene boundary in P34 is absent at this depth in borehole P35, where it does not occur until a depth of $218 \mathrm{~m}$ to $232 \mathrm{~m}$. The Gamma Ray logs at the same depths in both boreholes differ to a greater or lesser extent.

First analyses of the carbonate content and heavy minerals from isolated samples in borehole P35 (pers. com. C. Hoselmann, Hessisches Landesamt für Umwelt and Geologie) resulted in carbonate concentrations of 10 to $20 \%$ down to a depth of $190 \mathrm{~m}$ and carbonate contents of up to $3 \%$ between $190 \mathrm{~m}$ to $218 \mathrm{~m}$ (Fig. 3). The samples are non-calcareous beneath 218 $\mathrm{m}$. The spectrum of transparent heavy minerals also reveals a difference in composition below a depth of $218 \mathrm{~m}$. Garnet, epidote, alterite and hornblende dominate from $0 \mathrm{~m}$ to $218 \mathrm{~m}$. Stable heavy minerals such as zircon and tourmaline are only present in subordinate amounts. The spectra are typical for sediments deposited in the Pleistocene Rhine. The sequences are interrupted - as also confirmed in the P34 borehole (Hagedorn 2004, Hagedorn \& Boenigk 2008) - by sediments deposited by streams draining the Buntsandstein of the Pfälzerwald. These are characterised by heavy minerals dominated by tourmaline and higher concentrations of zircon. Below $218 \mathrm{~m}$, tourmaline and zircon are joined by significant proportions of the $\mathrm{TiO}_{2}$ group, as well as hornblende and garnet. Similar spectra occur in borehole P34 below the PlioPleistocene boundary. This characteristic later Pliocene heavy mineral spectrum is also shown in other boreholes drilled in the Northern Upper Rhine Graben, such as the Schifferstadt borehole (HAGEDORN 2004) and in Viernheim (Hoselmann 2008).

Nearly 1200 samples were taken from the P34 cores for pollen analysis. 120 samples were initially selected for a preliminary analysis and prepared at the laboratory operated by LGB Rheinland-Pfalz. This preliminary analysis 


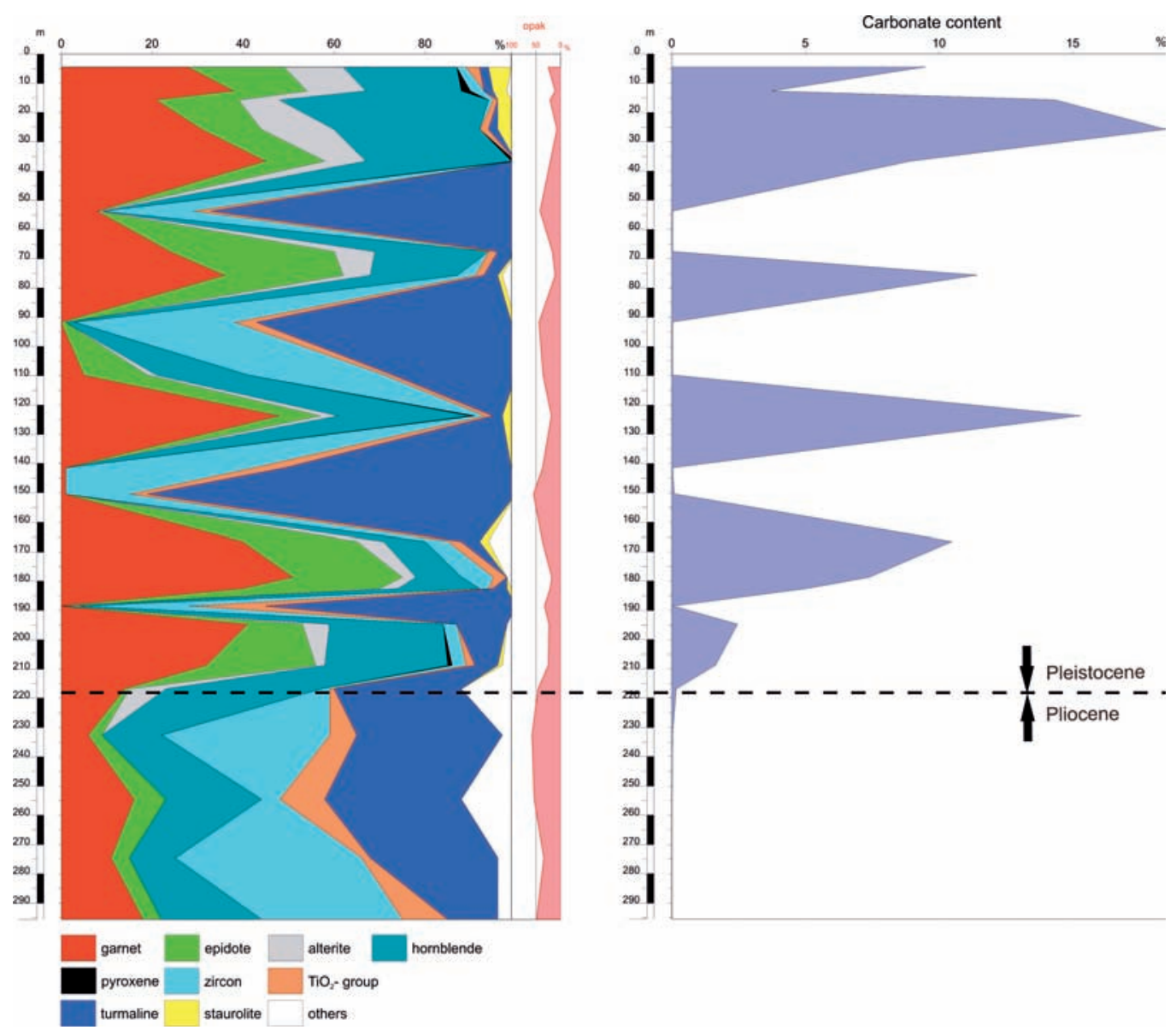

Fig. 3: Heavy mineral diagram and carbonate content of the Ludwigshafen P35 borehole (HoselmanN, pers. com.).

Abb. 3: Schwerminerale und Karbonatgehalt der Bohrung Ludwigshafen P35 (Hoselmann, pers. Mitt.).

involved a quick estimation of the pollen content, or counting only a minor number of pollen grains. 1600 pollen samples were taken from the P35 borehole, and 60 samples were looked at. 38 samples from the Maudach A 36 borehole also underwent preliminary analysis to roughly determine the pollen content, or subjected to counting a small number of pollen grains (Fig. 4, Fig. 5). The pollen sequences are mostly incomplete due to the variable tectonic subsidence of the URG and the fluvial dynamics which didn't allow a regular sedimentation.

The preliminary investigation of borehole P34 revealed at least parts of 5 interglacials and se- veral glacial pollen sequences (Fig. 4, Fig. 5). At a depth of 13,6 $\mathrm{m}$ in the lower, fine-grained section of the OKL, the pollen assemblage (LuI-A in Fig. 5) had high values of Corylus (hazel) as well as Picea (spruce) and Alnus (alder), and low values of Quercus (oak), Ulmus (elm), Carpinus (hornbeam) and Abies (fir), which may indicate the early part of an interglacial sequence or a part of a temperate interstadial. Another interglacial sequence was encountered in the OZH from 26.5-29.05 m. The lower part of this section (Lu-I-C) contains pollen from Abies, Carpinus and Taxus (yew), and massulae from Azolla filiculoides (large mosquito 


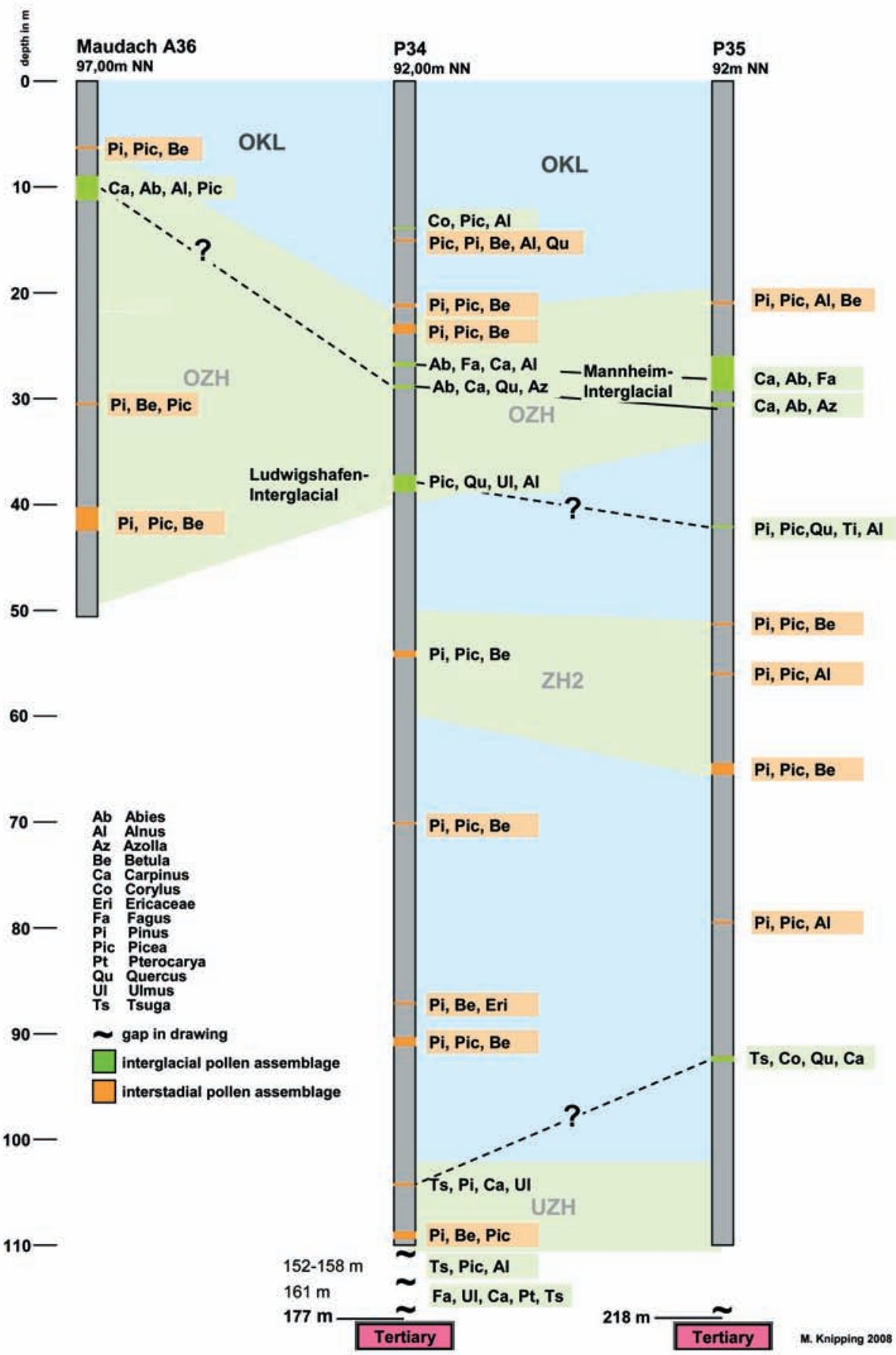

Fig. 4: Summary of the preliminary pollen analysis results from boreholes P34, P35 and Maudach A36. Abb. 4: Übersicht der pollenanalytischen Voruntersuchungen der Bohrungen P34, P35 und Maudach A36. 


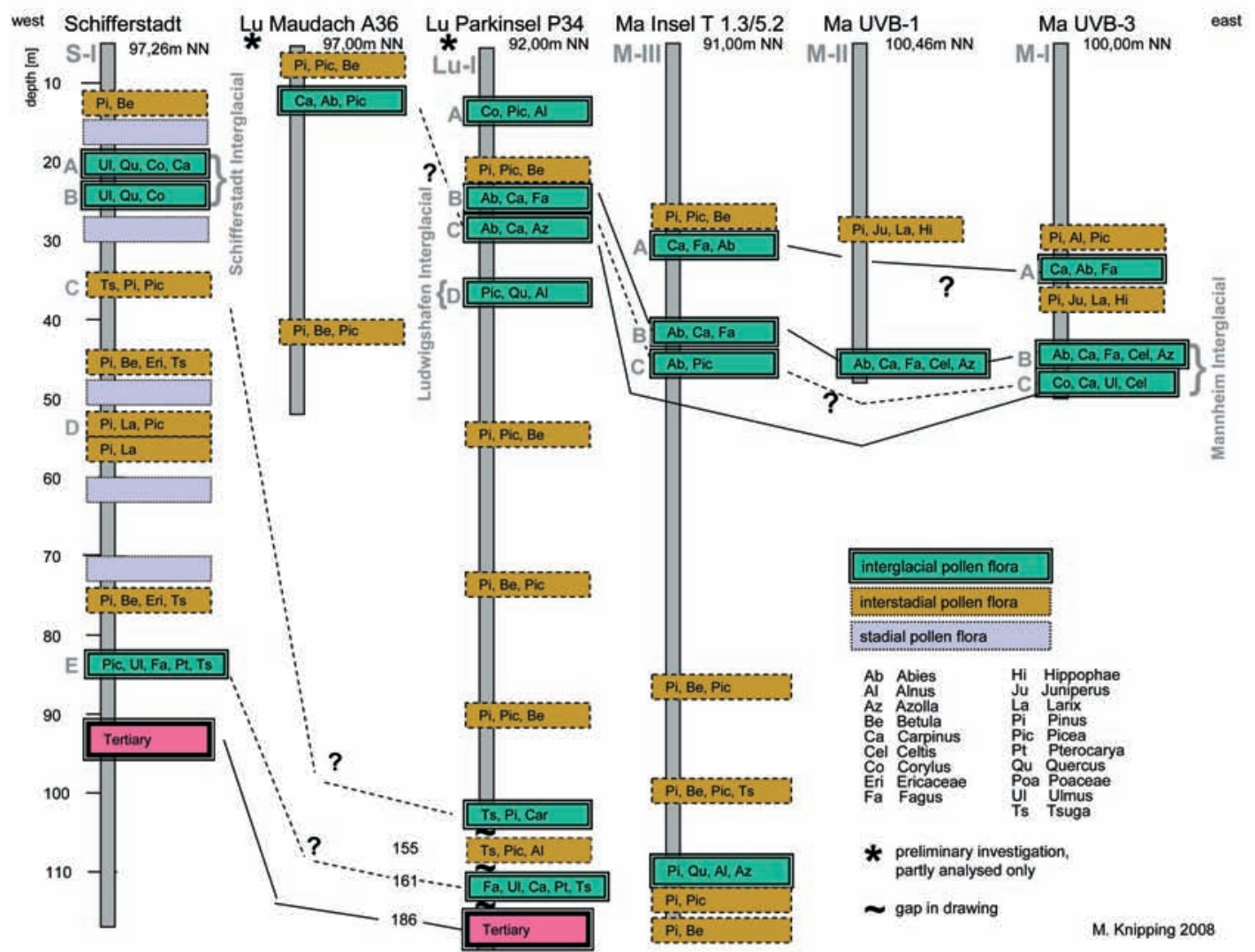

Fig. 5: Summary and preliminary correlation of the investigated pollen sections in the Schifferstadt/ Ludwigshafen/Mannheim area.

Abb. 5: Übersicht und vorläufige Korrelation der untersuchten Pollenprofile im Raum Schifferstadt/ Ludwigshafen/Mannheim.

fern), whilst the upper part (Lu-I-B) contains pollen from Fagus (beech). A further interglacial pollen assemblage (Lu-I-D, Ludwigshafen Interglacial) containing Picea, Quercus, Alnus, Ulmus and Corylus was present between 36.9 $-38.4 \mathrm{~m}$.

Two samples from the UZH $(103 \mathrm{~m})$ contain several grains of Tsuga (hemlock) in a pollen assemblage dominated by Pinus (pine), together with Picea, Carpinus and Ulmus. Other spectra with Tsuga, Picea, Alnus and Pinus occur at a depth of $152.4-158.4 \mathrm{~m}$. High concentrations of Fagus pollen alongside Quercus, Ulmus, Carpinus, Pterocarya (wingnut), Ostrya type (hop hornbeam) and Tsuga, were recovered at a depth of $161.45 \mathrm{~m}$. A Tertiary pollen spectrum was identified in two separate samples at 186 and $201 \mathrm{~m}$.

In the first analysis of borehole P35, which involved the zone down to a depth of $93 \mathrm{~m}$, there were at least three interglacial sequences alongside several glacial pollen spectra (Fig. 4). An analogous interglacial sequence was found at a similar depth to that in borehole P34. In the lower part of this sequence $(30.4-30.7 \mathrm{~m})$ pollen from Abies, Carpinus and Quercus were identified, along with massulae from Azolla. In the upper part $(26.2-29.0 \mathrm{~m})$, Fagus pollen was also found. The decline in pollen from thermophilous taxa (from $26.5 \mathrm{~m}$ ) and the marked increase in Pinus pollen appears to show the end of the interglacial. A pollen 
spectrum with Pinus, Picea, Corylus, Quercus and Alnus is also found at $42.1 \mathrm{~m}$. Two interglacial pollen spectra including Tsuga, as well as Corylus, Quercus and Carpinus were identified in fine-grained horizons $(91.1-92.45 \mathrm{~m})$ below the UZH.

In the $\mathrm{OZH}$ at Maudach A36 a pollen sequence $(9.0-11.2 \mathrm{~m})$ shows interglacial conditions characterised by high amounts of Carpinus (up to $40 \%$ ) shifting to woodland richer in Abies, then in Picea and dominated at last by Pinus and Betula. Until now Fagus is absent, even though several samples have been analysed. Pollen of Buxus has values up to $5 \%$ in the lower part of the interglacial.

\section{Discussion}

It should be stressed in advance that the following correlations are only tentative in character because they are based on preliminary analysis, and complete analysis of the samples still remains to be done. The pollen sequences recorded to date are often fragmentary and there are uncertainties when correlating these with other pollen sequences. Publications covering the boreholes from the Mannheim area (KNIPPING 2004, 2008) already include some of the results of the preliminary analysis of the P34 borehole, which provided an invaluable addition to and confirmation of the biostratigraphic classification of the penetrated sequences.

For the interglacial or temperate interstadial pollen spectrum at a depth of $13.6 \mathrm{~m}$ in the OKL in borehole P34, a Holocene or Eemian age can be rejected, but a correlation with either one of the Early Weichselian interstadials or an interglacial older than the Eemian is possible (KNIPPING 2008). No analogous pollen spectrum has so far been found in P35.

P34 contains pollen spectra $(26.5-29.05 \mathrm{~m})$ which are correlatable with a high degree of probability with the Middle Pleistocene Mannheim Interglacial (KNIPPING 2008). Borehole P35 (Fig. 4) also revealed pollen spectra at a similar depth which, because of the presence of Carpinus, Abies and Azolla in the lower part (30.4- $30.7 \mathrm{~m})$, and the additional occurrence of Fagus in the upper part of the interglacial $(26.2-29.0 \mathrm{~m})$, correlates with a high degree of probability with the interglacial in P34 (LuI-B + C) and therefore with the Mannheim Interglacial (Fig. 4, Fig. 5). According to the pollen spectra identified to date, the upper part of the interglacial is represented in P35 by a section with a thickness of $2.8 \mathrm{~m}$, and is thus much thicker than in P34 where the thickness is only $0.3 \mathrm{~m}$. The lower part of the interglacial has a similar thickness in both boreholes with a thickness of approx. $0.3 \mathrm{~m}$.

Comparison with other Middle Pleistocene interglacials indicates that the most likely correlation for the Mannheim Interglacial is with the Rhume Interglacial (MüLler 1986, 1992) and the Kärlich Interglacial (URBAN 1983, BitTMANN 1992). The interglacial section of Meikirch II (WeLten 1982, 1988) was recently reinterpreted by PREUSSER et al. (2004), and the former "Eemian" is now correlated with MIS 7. There are some similarities with the Mannheim Interglacial, but Celtis which is present in the Mannheim Interglacial as well as the Kärlich Interglacial is not present at Meikirch.

The interglacial found in the $\mathrm{OZH}$ in P34 at $36.9-38.4 \mathrm{~m}$ (Lu-I-D) is primarily characterised according to the current degree of analysis by the absence of Carpinus, Abies and Fagus. There are some similarities to the pre-Rhume thermomere described by MüLLER (1992) and the interglacial found by BLUDAU (2001) at approx. $47-52 \mathrm{~m}$ in the Mannheim Ergo BK 3 borehole. Interglacial pollen spectra without Carpinus, Abies and Fagus were only found in two horizons at $42 \mathrm{~m}$ in borehole P35. It is not certain at this stage whether these correlate with Lu-I-D. Should this correlation be confirmed, then there is a very marked difference in the thickness of the sequence in P34 $(1.5 \mathrm{~m})$ and the $0.1 \mathrm{~m}$ thick sequence in P35.

Another cored borehole in the Ludwigshafen area (Maudach A36) was also included in this preliminary analysis (Fig. 1, Table 1). An interglacial with high proportions of Carpinus is reported in the $\mathrm{OZH}$ at a depth of $9-11.2 \mathrm{~m}$. Based on the current status of the preliminary analysis, this cannot be correlated with the 
younger part of the Mannheim Interglacial because no Fagus has been found. It is possible that this interglacial correlates with the older part of the Mannheim Interglacial. If this is true, the Mannheim Interglacial represents two separate interglacials because the end of the interglacial appears to have been reached in Maudach A36 with the transition to Pinusricher sections. The presence of a gastropod fauna in the same borehole at a depth of 23 - $28 \mathrm{~m}$, which WedEL (2008) interprets as indicating the Cromerian Complex, could indicate a possible classification as Cromerian. Another consequence of a correlation between Maudach with the older part of the Mannheim Interglacial would be to make the correlation between the Mannheim Interglacial with the earlier "Eemian" at Meikirch (Preusser et al. 2004) very unlikely (see above), because Carpinus pollen is very rare in the two lower interglacials of Meikirch "Holstein 1" and "Holstein 2" (Welten 1982, 1988), but accounts for nearly $40 \%$ in Maudach. The Upper Pleistocene position of the interglacial at Maudach at a depth of $9-11.2 \mathrm{~m}$ cannot, however, be excluded on the basis of the current status of the pollen analysis.

Interdisciplinary analysis in the northern part of the Upper Rhine Graben, which in addition to looking at the lithostratigraphy, also looks at "Upper Pleistocene" mammal remains, gastropods, wood remains and pollen, provided no reliable stratigraphic classification of the material (Koenigswald 1988). Dating of parts of the Upper Gravels (OKL) and the "Oberer Ton" (Upper Clay = OZH) to the last interglacial (Eemian) has, however, been favoured by some authors. However, the latest analysis by KNIPPING (2002, 2004, 2008) and Wedel (2008) has shown that the OZH in the Mannheim/Ludwigshafen area cannot be assigned to the Eemian but must be older. The analysis of gastropods from the "Upper Clay" in the Mannheim-Lindenhof borehole (RÄHLE 2005) gave a Middle Pleistocene, probably Cromerian age. The same samples contained analogous pollen spectra to those found in the Mannheim Interglacial (KNIPPING, unpub- lished). This, as well as the work of ENGESSER \& MüNZING (1991) in the Mannheim area support the palynological correlation of the $\mathrm{OZH}$ with the Cromerian Complex. Two boreholes of Mannheim (KNIPPING 2004, 2008) contained additional pollen from thermophilous taxa above the Mannheim Interglacial, including Carpinus and Fagus (Fig. 5). Because these are only single samples, the question still remains open of whether these can be correlated with interglacials younger than the Mannheim Interglacial. It does, however, support the correlation of the Mannheim Interglacial with the Cromerian Complex.

No Middle Pleistocene pollen spectra with Pterocarya, which could be correlated with the Holstein/Pterocarya Interglacial (MüLLER 1974, Grüger 1983, Drescher-SchNeIDER 2000) have so far been identified in the boreholes in Mannheim, Schifferstadt or Ludwigshafen. The Schifferstadt Interglacial described in the Schifferstadt borehole (KNIPPING 2002), is also probably equivalent to the Ferdynandowian Interglacial (JANCZYK-KoPIKOwA 1975), and has also not been identified so far in the two boreholes in Ludwigshafen.

Increased subsidence of sub-blocks during the Plio-Pleistocene in the northern Upper Rhine Graben around the Mannheim/Heidelberg area is not only indicated lithostratigraphically, but also by pollen analysis. According to the initial investigation, the P34 and P35 boreholes penetrated sediments down to a depth of $102 \mathrm{~m}$ in which at least 3 superposed interglacials have been partially identified (KNIPPING 2004, 2008). Tsuga occurs from approximately $103 \mathrm{~m}$ in P34 and $92 \mathrm{~m}$ in P35, which currently still indicates a Lower Pleistocene age. Notable in this context is the single identification of a Tsuga pollen grain in the lower part of the Mannheim Interglacial (UVB-3) (Fig. 5) (KNIPPING 2008). Indications that Tsuga could also be present in the Cromerian Complex are supported by the analysis conducted by BLUDAU (2001) in the Mannheim Ergo BK3 borehole. The author describes several isolated occurrences of Tsuga in an interglacial and discusses a possible Cromerian age. In addition, in the Schifferstadt 


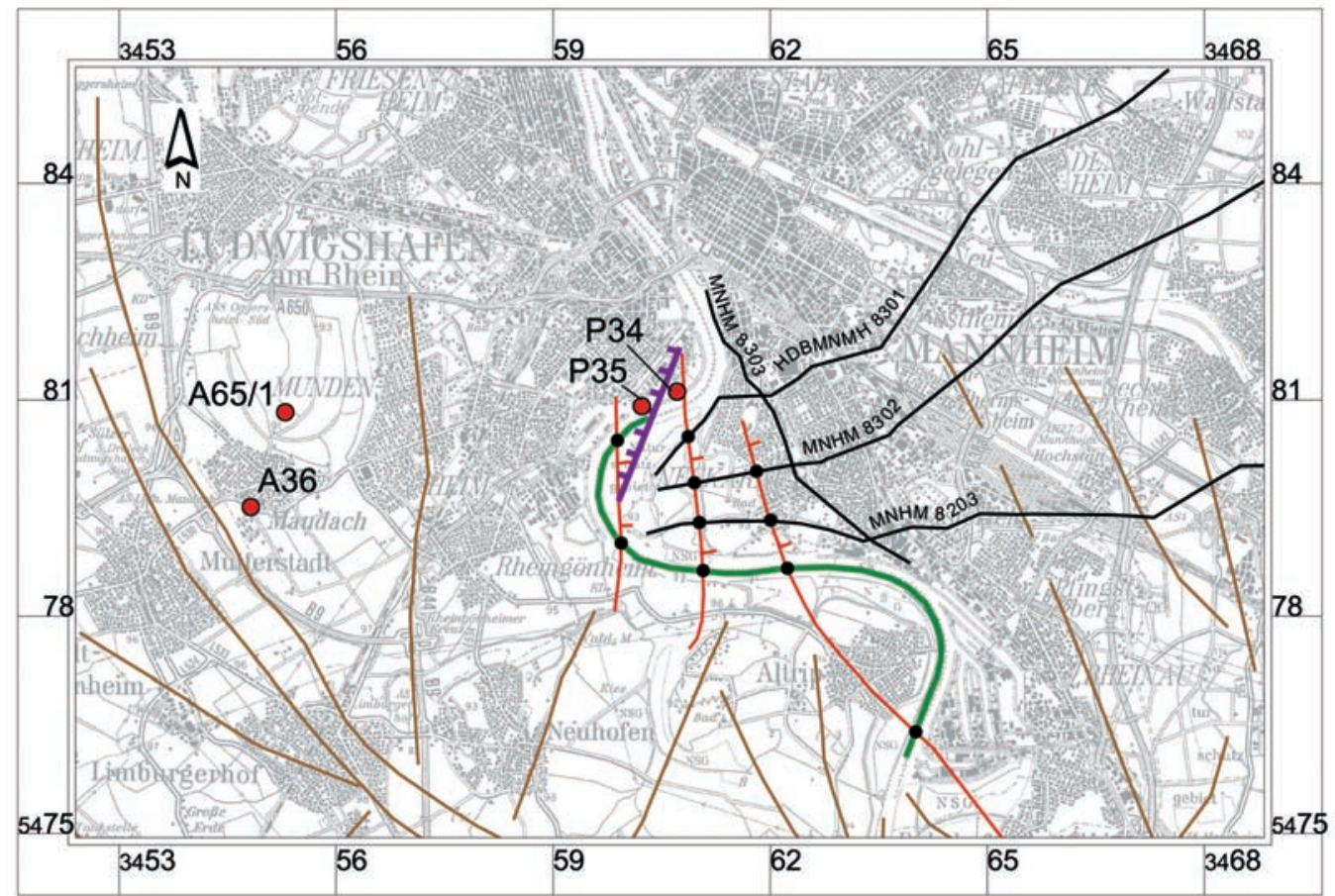

0

5

10 Kilometer

\section{Position of the Rhine seismic profile including position of the quaternary faults \\ $\wedge$ Position of the industrial seismic profiles including position of the identified faults (only western part) \\ A Assumed position of the quaternary faults (after WIRSING et al. 2007) \\ Fault system at the surface of oligocene (after ANDRES \& SCHAD 1959) \\ $\downarrow v$ Assumed position of a fault between the P34 and P35 boreholes}

Fig. 6: Assumed position of a fault between the Ludwigshafen P34 and P35 boreholes, depicting the position of the Quaternary faults, interpreted on the basis of industrial seismic and river seismic profiles (after WIRSING et al. 2007).

Abb. 6: Vermuteter Verlauf der Störung zwischen den Bohrungen Ludwigshafen P34 und P35 mit Darstellung des Verlaufs quartärer Störungen, entwickelt aus industrieseismischen und flussseismischen Profilen (nach WIRSING et al. 2007).

borehole lying further to the west (KNIPPING 2002), which is also described as containing a Middle Pleistocene interglacial (Schifferstadt Interglacial), several occurrences of Tsuga have been confirmed at depths below $36 \mathrm{~m}$. This section has therefore been preliminarily correlated with the Lower Pleistocene down to the Plio-Pleistocene boundary at approximately
$91 \mathrm{~m}$. The Middle-Lower Pleistocene boundary and Quaternary base deepen in these boreholes from west to east in the direction of the centre of the Heidelberg Basin. The Quaternary base in the Viernheim research borehole is at a depth of $224 \mathrm{~m}$ (Hoselmann 2008).

Lower Pleistocene and Tertiary sediments from the northern Upper Rhine Graben have mainly 
been looked at in the Schifferstadt borehole. Various interglacial and glacial vegetation sequences were described here in the older sections (KNIPPING 2002). Lower Pleistocene sediments have so far only been recorded in the P34 borehole. The occurrence of Tsuga pollen, together with Picea, Alnus and Pinus at 152.4 - $158.4 \mathrm{~m}$, points more to cool climatic conditions, but no detailed biostratigraphic subdivision is currently possible. Pollen spectra with high proportions of Fagus, in addition to Tsuga, Pterocarya, Carpinus, Quercus and Picea, occur at $160.45-161.45 \mathrm{~m}$. Because of the common occurrence of Fagus, it can probably be classified as lying within the Tegelen Complex, probably Tegelen A (ZAGWiJn 1963). Tertiary pollen spectra at 186 and $201 \mathrm{~m}$ in P34, combined with heavy mineralogical and palaeomagnetic and rock-magnetic analysis, confirm the Plio-Pleistocene boundary at 177 $\mathrm{m}$. No pollen analysis has yet been carried out on the Lower Pleistocene and Pliocene sections in borehole P35.

The new results of the analyses of borehole P35 (heavy minerals, carbonate content, lithofacies profile, gamma ray $\log$ ) indicate that the PlioPleistocene boundary in borehole P35 is not at $183 \mathrm{~m}$ depth as implied by the first interpretation, but probably more likely at a depth of 218 $\mathrm{m}$. Because the base of the Quaternary in the P34 borehole was confirmed at a depth of 177 m (KNipping 2008, Rolf et al. 2008), the PlioPleistocene boundary in borehole P35 probably lies approximately $42 \mathrm{~m}$ deeper. The large difference in depth within a distance of only $500 \mathrm{~m}$ cannot be explained by fluvial dynamics alone. It is more likely that the two boreholes are separated by a fault, and that borehole P34 lies on the upthrown and P35 on the downthrown side of the fault. The river seismic survey shot on the Rhine, and the interpretation of industrial seismic sections, indicate the presence of young faults in the Ludwigshafen/ Mannheim area (Bertrand et al. 2006, HaimBERGER et al. 2005, WIRSING et al. 2007). These easterly dipping faults indicate the en-echelon faulted subsidence of the Quaternary base from west to east in the direction of the centre of the
Heidelberg Basin (Fig. 6). Throws of up to 10 $\mathrm{m}$ at the base of seismic horizon $2(\mathrm{OZH}$ and Middle Sandy-Gravely Series) are interpreted from the seismic sections. In general, the faults identified in the Ludwigshafen/Altrip area can be linked to three NNW-SSE running, easterly dipping antithetic downthrown faults (WIRSING et al. 2007). Because the drilling location of borehole P34 lies approximately $500 \mathrm{~m}$ ENE of borehole P35, it must be assumed that a sub-block lying further to the west has subsided more strongly (P35), an anomaly when compared to the regional situation. It is possible that a previously unidentified WNWESE running transverse fault separates this sub-block from the easterly lying sub-block on which borehole P35 was drilled. Indications of young tectonic movements in the northern Upper Rhine Graben are documented in numerous recent publications (Peters et al. 2005, Peters \& van BALEN 2007a, 2007b, Weidenfeller \& KÄRCHER 2008). Interestingly, the Quaternary faults are very closely related to faults which cut the Tertiary sediments and the base of the Tertiary (Andres \& Schad 1959, Derer et al. 2005).

Because the upper $122 \mathrm{~m}$ of the P34 and P35 boreholes can be very well correlated in terms of thickness, as well as sedimentary facies and gamma logs, it is assumed that tectonism was particularly active prior to the start of sedimentation of the Lower Intermediate Horizon (UZH), and that it then weakened considerably. Because the $\mathrm{OZH}$ is assigned to the Cromerian Complex on the basis of current findings (KNIPPING 2008, RÄHLE 2005, WEDEL 2008), and because the UZH is also assigned to the transition zone between the Lower and Middle Pleistocene, the phase of tectonism giving rise to the approximately $42 \mathrm{~m}$ throw is considered to have taken place during the latest Pliocene and Lower Pleistocene. It seems clear that this period was characterised by more rapid subsidence of the Heidelberg Basin, and thus the Ludwigshafen-Mannheim area as well, and that this rapid subsidence was compensated for by high rates of sedimentation. 


\section{Conclusions}

Fluctuating fluvial dynamics over very short distances leave behind strongly differentiated sequences in the geological record which can only be approximately interpreted with the information gained from several cores. The differences in the nature of the sediments between the P34 and P35 boreholes highlights that the interpretation of the climatic and fluvial history of an area on the basis of the analysis of a few boreholes becomes very difficult because the sediments are not only affected by fluvial dynamics, but also by small-scale tectonics. The complex fault pattern in the northern Upper Rhine Graben is partially responsible for the preservation and character of the sediments. Unlike major cycles which can still be recognised and correlated across several boreholes, closer analysis reveals the presence of frequent gaps which make interpretation more difficult. Sedimentation is often controlled by young tectonics where small-scale fault block movements can result in the deposition of very different sequences of sediments, as recorded in the cores. The clear characterisation and stratigraphic identification based on several independent methods, and on pollen analysis in particular, provides the information required to make reliable interpretations of the sedimentation history influenced by palaeoclimatic fluctuations and tectonic movements. The differences identified by comparing the two boreholes P34 and P35, which are only $500 \mathrm{~m}$ apart, emphasise that the large-scale correlation of boreholes separated from one another by several tens of kilometres, will only succeed when the sediments in the cores are analysed using analogous methods and can be stratigraphically classified.

\section{Acknowledgments}

For fruitful discussions we have to thank Dietrich Ellwanger (LGRB Freiburg), Christian Hoselmann (HLUG Wiesbaden), Christian Rolf (Leibniz Institute for Applied Geophysics) and Thomas Kärcher (LGB
Mainz). We like to thank Marion Mays and Anke Hildebrandt (LGB Mainz) for preparing the pollen samples.

\section{References}

Andres, J. \& Schad, A. (1959): Seismische Kartierung von Bruchzonen im mittleren und nördlichen Teil des Oberrheingrabens und deren Bedeutung für die Ölansammlung. - Erdöl und Kohle, 12: 323-334.

BARTZ, J. (1959): Zur Gliederung des Pleistozäns im Oberrheingraben. - Zeitschrift der deutschen geologischen Gesellschaft, 111: 653-661.

BarTZ, J. (1974): Die Mächtigkeit des Quartärs im Oberrheingraben. - In: Illies, H. \& Fuchs, K. (eds.): Approaches to Taphrogenesis. - InterUnion Commission on Geodynamics Scientific Report, 8: 78-87; Stuttgart (Schweizerbart).

Bertrand, G., Elsass, P., Wirsing, G. \& Luz, A. (2006): Quaternary faulting in the Upper Rhine Graben revealed by high-resolution multi-channel reflection seismic. - Comptes Rendus Geoscience, 338: 574-580.

Bittmann, F. (1992): The Kärlich Interglacial, Middle Rhine region, Germany: vegetation history and stratigraphic position. - Vegetation History and Archaeobotany, 1: 243-258.

Bludau, W. (2001): Preliminary results of pollenanalytical investigations in the northern part of the Upper Rhine Valley. - Internal report: 2 pp.

Derer, C.E., Schumacher, M.E. \& Schäfer, A. (2005): The Northern Upper Rhine Graben: basin geometry and early syn-rift tectono-sedimentary evolution. - International Journal of Earth Sciences (Geologische Rundschau), 94: 640-656.

Drescher-Schneider, R. (2000): 2. Halt: Kiesgrube Thalgut: Pollen- und großrestanalytische Untersuchungen. - In: Kelly, M., Linden, U. \& SCHLÜChTER, C.: Exkursionsführer DEUQUA 2000, Eiszeitalter und Alltag, Bern 6.-8. September 2000: 128-136; Bern.

Ellwanger, D., Gabriel, G., Hoselmann, C., LÄmmermann-Barthel, J. \& Weidenfeller, M. (2005): The Heidelberg Drilling Project (Upper Rhine Graben, Germany). - Quaternaire, 16(3): 191-199.

Engesser, W. \& MüNZING, K. (1991): Molluskenfaunen aus Bohrungen im Raum Phillipsburg-Mannheim und ihre Bedeutung für die Quartärstratigraphie des Oberrheingrabens. 
- Jahreshefte des Geologischen Landesamts Baden-Württemberg, 33: 97-117.

GRÜGER, E. (1983): Untersuchungen zur Gliederung und Vegetationsgeschichte des Mittelpleistozäns am Samerberg in Oberbayern. - Geologica Bavarica, 84: 21-40.

Hagedorn, E.-M. (2004): Sedimentpetrographie und Lithofazies der jungtertiären und quartären Sedimente im Oberrheingebiet. - Dissertation Universität zu Köln: 248 pp.; Köln.

Hagedorn, E.-M. \& Boenigk, W. (2008): New evidences of the Pliocene and Quaternary sedimentary and fluvial history in the Upper Rhine Graben on basis of heavy mineral analysis. $-\mathrm{Ne}-$ therlands Journal of Geosciences, 87(1): 21-32.

Haimberger, R., Hoppe, A. \& Schäfer, A. (2005): High-resolution seismic survey on the Rhine River in the northern Upper Rhine Graben. - International Journal of Earth Sciences (Geologische Rundschau), 94(4): 657-668.

Han, J., Fyfe, W.S., Longstaffe, F.J., Palmer, H.C., YAN, F.H. \& MAI, X.S. (1997): Pliocene-Pleistocene climatic change recorded in fluviolacustrine sediments in central China. - Palaeogeography, Palaeoclimatology, Palaeoecology, 135: 27-39.

Heller, F. \& Liu, T. S. (1982): Magnetostratigraphical dating of loess deposits in China. - Nature, 300: 431-433.

Hoselmann, C. (2008): The Pliocene and Pleistocene fluvial evolution in the Northern Upper Rhine Graben based on results of the research borehole at Viernheim (Hessen, Germany). - Eiszeitalter und Gegenwart (Quaternary Science Journal), 57/3-4: 286-315.

JANCZYK-KopiKowa, Z. (1975): Flora of the Mazovian Interglacial at Ferdynandów. - Biuletyn Institut Geologica, 290: 1-94.

KärCHER, Th. (1987): Beiträge zur Lithologie und Hydrogeologie der Lockergesteinsablagerungen (Pliozän, Quartär) im Raum Frankenthal, Ludwigshafen-Mannheim, Speyer. - Jahresberichte und Mitteilungen des Oberrheinischen Geologischen Vereines, N.F. 69: 279-320.

KNIPPING, M. (2002): Pollenanalytische Untersuchungen am Profil „Schifferstadt BK 30c GM“. - Arbeitsbericht Geologisches Landesamt Rheinland-Pfalz: 11 pp.; Mainz.

KnIPPING, M. (2004): Pollenanalytische Untersuchungen an einem mittelpleistozänen Interglazial bei Mannheim. - Tübinger Geowissenschaftliche Arbeiten D10: 199-217.

KnIPPING, M. (2008): Early and Middle Pleistocene pollen assemblages of deep core drillings in the northern Upper Rhine Graben, Germany. - Netherlands Journal of Geosciences, 87(1): 51-65.

Koenigswald, W. von. (ed.) (1988): Zur Paläoökologie des letzten Interglazials im Nordteil der Oberrheinebene. - Paläoklimaforschung, 4: $327 \mathrm{pp}$.

Menzies, J. (2006): A Report on Samples from Ludwigshafen-Parkinsel. - Brock University: 30 pp.; St. Catharines, Canada.

MülLER, H. (1974): Pollenanalytische Untersuchungen und Jahresschichtenzählungen an der holsteinzeitlichen Kieselgur von Munster-Brehloh. - Geologisches Jahrbuch, A21: 107-140.

MülLER, H. (1986): Altquartäre Sedimente im Deckgebirge des Salzstockes Gorleben. - Zeitschrift der deutschen geologischen Gesellschaft, 137: 85-95.

MülLER, H. (1992): Climate changes during and at the end of the interglacials of the Cromerian Complex. - In: KuKLA, G. J. \& Went, E. (eds): Start of a Glacial. - NATO ASI Series, 13: 55-69.

Peters, G., Buchmann, T.J., Connolly, P., van Balen R.T., Wenzel, F. \& Cloetingh, S.A.P.L. (2005): Interplay between tectonic, fluvial and erosional processes along the Western Border Fault of the northern Upper Rhine Graben, Germany. - Tectonophysics, 406: 39-66.

Peters, G. \& van Balen, R.T. (2007a): Pleistocene tectonics inferred from fluvial terraces of the northern Upper Rhine Graben, Germany. - Tectonophysics, 430: 41-65.

Peters, G. \& van Balen, R.T. (2007b): Tectonic geomorphology of the northern Upper Rhine Graben, Germany. - Global Planetary Change, 58: 310-334.

Preusser, F., Drescher-Schneider, R., Fiebig, M. \& SchlÜChteR, C. (2004): Re-Interpretation der Meikirch-Bohrungen, Aaretal, und Konsequenzen für die Quartärstratigraphie in der Schweiz. - DEUQUA meeting 30. August - 3. September, Abstract Volume: 67; Nijmwegen.

RÄHLE, W. (2005): Eine mittelpleistozäne Molluskenfauna aus dem Oberen Zwischenhorizont des nördlichen Oberrheingrabens (Bohrung Mannheim-Lindenhof). - Mainzer Geowissenschaftliche Mitteilungen, 33: 9-20.

Rolf, C., Hambach, U. \& Weidenfeller, M. (2008): Rock and palaeomagnetic evidence for the PlioPleistocene palaeoclimatic change recorded in Upper Rhine Graben sediments (Core Ludwigshafen-Parkinsel). - Netherlands Journal of Geosciences, 87(1): 41-50. 
URBAN, B. (1983): Biostratigraphic correlation of the Kärlich Interglacial, northwestern Germany. - Boreas, 12: 83-90.

Shackleton, N. J., Blackman, J., Zimmerman, H., Kent, D.V., Hall, M.A., Roberts, D. G., Schnitker, D., Baldauf, J.G., Desprairies, A., Homrighausen, R., Huddlestun, P., Keene, J.B., Kaltenback, A.J., Krumsiek, K.A.O., Morton, A.C., Murray, J.W. \& Westberg, S.J. (1984): Oxygen isotope calibration of the onset of icerafting and history of glaciation in the North Atlantic region. - Nature, 307: 620-623.

Wedel, J. (2008): Pleistocene molluscs from research boreholes in the Heidelberg Basin. - Eiszeitalter und Gegenwart (Quaternary Science Journal), 57/3-4: 382-402.

WeIDENFeller, M. \& KärCher, T. (2008): Tectonic influence on fluvial preservation: aspects of the architecture of Middle and Late Pleistocene sediments in the northern Upper Rhine Graben, Germany. - Netherlands Journal of Geosciences, 87(1): 33-40.
Welten, M. (1982): Pollenanalytische Untersuchungen im Jüngeren Quartär des nördlichen Alpenvorlandes der Schweiz. - Beiträge zur Geologischen Karte der Schweiz, N. F. 156: 174 S. + Diagrammheft.

Welten, M. (1988): Neue pollenanalytische Ergebnisse über das Jüngere Quartär des nördlichen Alpenvorlandes der Schweiz (Mittel- und Jungpleistozän). - Beiträge zur Geologischen Karte der Schweiz, N. F. 162: 40 S. + 20 Diagramme.

WERNER, S. (2006): Wärmeleitfähigkeitsmessungen an Kernen der $300 \mathrm{~m}$ Bohrung Parkinsel2/ Ludwigshafen. - Diplomarbeit TU Clausthal: 128 pp.; Clausthal.

Wirsing, G., Luz, A., Engesser, W. \& Koch, A. (2007): Hochauflösende Reflexionsseismik auf dem Rhein und dem Rheinseitenkanal zwischen Mannheim und Rheinfelden. - LGRB-Fachbericht, 1/07: 60 pp.; Freiburg.

Zagwisn, W. H. (1963): Pollen-analytic investigations in the Tiglian of the Netherlands. - Mededelingen van de Geologische Stichting, N. S., 16: 49-71. 